\title{
Dyslipidemic profile in healthy women in relation to body fat distribution
}

\author{
Slavica Shubeska Stratrova ${ }^{1 *}$, Elena Kostova ${ }^{2}$ \\ ${ }^{1}$ Clinic of Endocrinology, Diabetes and Metabolic Disorders, Faculty of Medicine, \\ Ss. Cyril and Methodius University, Majka Tereza 17, 1000 Skopje, \\ Republic of North Macedonia \\ ${ }^{2}$ Department of Preclinical and Clinical Pharmacology and Toxicology, \\ Faculty of Medicine, Ss. Cyril and Methodius University, 50 Divizija 6, \\ 1000 Skopje, Republic of North Macedonia
}

Received: November 2019; Accepted: January 2020

\begin{abstract}
Abdominal obesity is associated with particularly adverse lipidemic profile. The aim of this study was to determine the characteristics of the dyslipidemic profile in healthy women with extreme abdominal obesity determined anthropometrically. Lipid profile and atherogenic indexes were determined in 80 healthy women, grouped in 4 groups according to their body mass index (BMI) and grouped in 3 groups according to their body fat distribution (BFD) by means of anthropometric indexes waist/hip ratio (WHR) and waist/thigh ratio circumference (WTR): group M with normal BFD (WHR $<0.85$ and WTR $<1.45$ ), group $\mathrm{N}$ with moderate (WHR $0.85-1$ and WTR 1.45-1.7) and group O with extremely expressed abdominal BFD.

HDL-cholesterol (HDL-C) levels $(0.84 \pm 0.26 \mathrm{mmol} / \mathrm{L})$ were significantly lowest in group $\mathrm{O}(\mathrm{p}<0.002)$, and significantly lower compared to group $\mathrm{N}(1.14 \pm 0.43 \mathrm{mmol} / \mathrm{L})(\mathrm{p}<0.006)$. Triglyceride $(\mathrm{TG})$ levels were significantly higher in group $\mathrm{O}$ compared to group $\mathrm{M}$ $(\mathrm{p}<0.001)$ and also higher in group $\mathrm{N}$ compared to group $\mathrm{M}(\mathrm{p}<0.044)$. Atherogenic indexes C/HDL-C, LDL/HDL-C and TG/HDL-C values in group $\mathrm{O}$ were significantly higher compared to the corresponding values in group $\mathrm{M}(\mathrm{p}<0.004 ; \mathrm{p}<0.006$; $\mathrm{p}<0.001)$, and their values were also higher in group $\mathrm{O}$ compared to group $\mathrm{N}$, but with lower significance of the difference $(\mathrm{p}<0.05)$ indicating lower increase of the atherogenic indexes in moderate and significant increase in women with extreme abdominal obesity.

Dyslipidemic profile and high atherogenic indexes in women with abdominal obesity with significantly highest WHR, WTR and BMI values indicated the need to intervene earlier and more effectively in the prevention and treatment of cardiovascular and metabolic risks.
\end{abstract}

Keywords: abdominal obesity, anthropometric indexes, lipid profile, atherogenic indexes

\section{Introduction}

Obesity is a medical condition in which excess body fat has accumulated to the extent that it may have an adverse effect on health, leading to reduced life expectancy and/or increased health problems (Vallgarda et al., 2017). Obesity is often multi-factorial, based on both, genetic and behavioural factors and it is a chronic disease of increasing prevalence, and therefore is rapidly becoming a major health issue in modern society. Central, abdominal, android or visceral obesity is associated with an increased risk of metabolic disorders and occurrence of chronic diseases compared to gynecoid obesity, which has a relatively peripheral gluteal/femoral distribution. Central, abdominal obesity can be an early warning sign

\footnotetext{
*slavass02@yahoo.com
} 
of a condition called metabolic syndrome. Metabolic syndrome is a multiplex risk factor that arises from insulin resistance accompanying abnormal adipose deposition and function. The main characteristic of the metabolic syndrome is the increased body weight, and particularly central, abdominal obesity that is associated with particularly adverse lipidemic profile, comprising increased $\mathrm{TG}$ and reduced HDL levels and insulin resistance (Lesser et al., 2015). Visceral obesity has also been directly linked to an increased risk of coronary heart disease (CHD), independent of whole-body obesity and to an increased risk of diabetes. This combination of factors creates an especially high risk for stroke, coronary artery disease, hypertension, cardiovascular disease-related mortality and type 2 diabetes, fatty liver and several cancers, and a number of other chronic diseases, when compared with individuals of normal weight and BFD (Lesser et al., 2015; Matsuzawa, 2014).

The quantification of visceral obesity is best determined by imaging exams such as Computed Tomography (CT), which is a gold standard method, but it requires high cost, difficult operation and radiation exposure. Intraabdominal fat weight measured by CT is highly correlated with abdominal, trunk fat weight measured by dual-energy X-ray absorptiometry (DXA). On the other hand, some anthropometric clinical indicators are easily obtained, they are accurate in estimating abdominal obesity, easy to use and have low cost enabling clinical assessment and the possibility to intervene earlier and more effectively in the prevention and/or treatment of the risks obesity. Strong correlation of waist hip ratio (WHR) and waist thigh ratio (WTR) with the visceral fat area was observed (Roriz et al., 2011, 2014a, 2016).

The aim of this study was to use clinical anthropometric indicators WHR and WTR in estimating abdominal, visceral obesity and their relationship with dyslipidemic profile and atherogenic indexes in healthy women in assessing the need to intervene earlier and more effectively in the prevention and treatment of cardiovascular and metabolic risks in abdominal obese women with dyslipidemic atherogenic profile.

\section{Materials and methods}

Triglycerides (TG), total cholesterol (C), cholesterol ester (CE), high density lipoprotein cholesterol (HDL-C), low density lipoprotein cholesterol (LDL-C) expressed in $\mathrm{mmol} / \mathrm{L}$ and atherogenic indexes: C/HDL-C, LDL/HDL-C and TG/HDL-C were determined in a total of 80 healthy women without complications, with a mean age of $32.7 \pm 12$ years divided in 4 groups according to their body mass index $(\mathrm{BMI}), 1^{\text {st }}$ group: $<25 \mathrm{~kg} / \mathrm{m}^{2}, 2^{\text {nd }}: 25-29.9 ; 3^{\text {rd }}$ : $30-34.9$ and $4^{\text {th }}$ group: $>35 \mathrm{~kg} / \mathrm{m}^{2}$.

The examinees were also grouped in 3 groups according to their body fat distribution (BFD) by means of anthropometric indexes waist/hip (WHR) and waist/thigh circumference ratio (WTR): group $M$ with normal BFD (WHR<0.85 and WTR<1.45), group $\mathrm{N}$ with moderate (WHR 0.85-1 and WTR 1.45-1.7) and group $O$ with extremely expressed visceral body fat distribution (WHR>1.0 and WTR>1.7). Anthropometric parameter WHR was determined by dividing waist circumference by hip circumference. It was an indicator used to identify the type of body fat distribution, as well as WTR which is found by dividing the waist circumference by the thigh circumference.

Body height was measured by a wall stadiometer in barefoot subjects with head in a horizontal Frankfurt plane to the nearest $0.1 \mathrm{~cm}$. Body weight was measured by a digital scale while wearing light clothing and it was estimated in kilograms $(\mathrm{kg})$. BMI was calculated with the following formula: weight $(\mathrm{kg}) /$ height $\left(\mathrm{m}^{2}\right)$.

Statistical analyses were performed using the statistical software program SPSS for Windows, version 19.0. $\mathrm{P}$ values $<0.05$ were considered to be statistically significant. The Kruskal-Wallis test is a rank-based nonparametric (distribution free) test that was used to determine statistically significant differences between three and four groups of an independent variable. It's an extension of the Mann-Whitney $U$ test, a nonparametric test that was used for comparing only two groups. The one-way analysis of variance (ANOVA) was used to determine whether there are any statistically significant differences between the means of three and four independent groups.

\section{Results}

Age, BMI, body weight and body height, anthropometric indexes WHR and WTR were investigated as well as lipid profile and atherogenic indexes.

The four groups of the examined healthy women divided according to their BMI were not significantly different with respect to their age and height, but were significantly different with respect to their body weight $(\mathrm{p}<0.0001)$. WHR values in the $3^{\text {rd }}$ and $4^{\text {th }}$ group were significantly higher compared to the $1^{\text {st }}$ and $2^{\text {nd }}$ group $(p<0.0001)$, but they were not significantly different between the $1^{\text {st }}$ and $2^{\text {nd }}$ group as well as between the $3^{\text {rd }}$ and $4^{\text {th }}$ group. WTR values were significantly higher in the $4^{\text {th }}$ group compared to the $1^{\text {st }}$ and $2^{\text {nd }}$ group $(\mathrm{p}<0.0001)$ and in the $3^{\text {rd }}$ group compared to the $1^{\text {st }}$ group $(\mathrm{p}<0.003)$ and to the $2^{\text {nd }}$ group $(\mathrm{p}<0.001)$ and with lower significance different to the $4^{\text {th }}$ group $(\mathrm{p}<0.021)$ confirming most expressed visceral body fat distribution in the $4^{\text {th }}$ group. The age of the examined women in this study was not significantly different when divided according to their BMI.

Total lipids, C, CE, LDL-C and TG were not significantly different among the groups according to the BMI values. C/HDL-C, LDL/HDL-C and TG/HDL-C values were significantly different $(p<0.012 ; \mathrm{p}<0.05$; 
Table 1. Age, BMI and anthropometric indexes in women grouped according to their BMI

\begin{tabular}{lccccc}
\hline \hline & group 1 & group 2 & group 3 & group 4 & p \\
\hline Age & $27.36 \pm 11.43$ & $32.86 \pm 10.93$ & $35.94 \pm 16.27$ & $34.97 \pm 13.08$ & NS \\
BMI & $18.49 \pm 0.51$ & $23.97 \pm 3.11$ & $32.83 \pm 2.25$ & $40.88 \pm 5.84$ & 0.0001 \\
body weight & $51.43 \pm 4.56$ & $63.39 \pm 11.14$ & $84.73 \pm 9.99$ & $104.12 \pm 18.49$ & 0.0001 \\
body height & $166.7 \pm 8.65$ & $161.87 \pm 9.42$ & $162.96 \pm 7.38$ & $159.67 \pm 7.69$ & NS \\
WHR & $0.795 \pm 0.013$ & $0.84 \pm 0.04$ & $0.95 \pm 0.06$ & $0.98 \pm 0.06$ & 0.0001 \\
WTR & $1.33 \pm 0.099$ & $1.36 \pm 0.11$ & $1.52 \pm 0.13$ & $1.62 \pm 0.14$ & 0.0001 \\
\hline N & 11 & 18 & 16 & 35 &
\end{tabular}

$\mathrm{p}<0.003)$ and HDL-C $(\mathrm{p}<0.018)$. C/HDL-C was significantly higher in the $4^{\text {th }}$ group compared to the $1^{\text {st }}$ group ( $\mathrm{p}<0.004)$, also LDL/HDL-C $(\mathrm{p}<0.021)$ as well as TG/HDL-C $(\mathrm{p}<0.001)$. HDL-C values were lowest in the $4^{\text {th }}$ group, significantly lower compared to the $1^{\text {st }}$ group $(p<0.006)$ and compared to the $2^{\text {nd }}$ group $(p<0.16)$.

The three groups of the examined healthy women divided according to the anthropometric parameters of abdominal, central body fat distribution had WHR and WTR values highly significantly different, as well as their BMI and body weight $(\mathrm{p}<0.0001)$. BMI values in group
$\mathrm{M}$ were significantly lower compared to group $\mathrm{N}$ and group $\mathrm{O}(\mathrm{p}<0.0001)$ and $\mathrm{BMI}$ values in group $\mathrm{N}$ were significantly lower compared to group $\mathrm{O}(\mathrm{p}<0.038)$. Body height was not different among the groups $(p>0.05)$. The age in group $\mathrm{O}$ was higher compared to group $\mathrm{M}$ $(\mathrm{p}<0.003)$ and was not different between group $\mathrm{M}$ and group $\mathrm{N}$ and between group $\mathrm{N}$ and group $\mathrm{O}$. These results indicated highest age and BMI in the extreme abdominal obese group $\mathrm{O}$. Abdominal BFD increase from group $\mathrm{M}$ to group $\mathrm{O}$ was characterized with $\mathrm{BMI}$, body weight, age, lipid atherogenic fractions increase, and HDL-C decrease.

Table 2. Lipid values according to their BMI

\begin{tabular}{|c|c|c|c|c|c|}
\hline & group 1 & group 2 & group 3 & group 4 & $\mathrm{p}$ \\
\hline Total lipids & $7.83 \pm 1.33$ & $7.79 \pm 1.55$ & $7.36 \pm 2.41$ & $8.28 \pm 1.31$ & NS \\
\hline Cholesterol & $5 \pm 0.99$ & $5.06 \pm 0.98$ & $5.04 \pm 0.91$ & $5.21 \pm 0.82$ & NS \\
\hline Cholesterol ester & $3.26 \pm 0.72$ & $3.39 \pm 0.69$ & $3.39 \pm 0.49$ & $3.5 \pm 0.58$ & NS \\
\hline HDL-C & $1.27 \pm 0.46$ & $1.09 \pm 0,36$ & $1.03 \pm 0.54$ & $0.95 \pm 0.26$ & 0.018 \\
\hline LDL-C & $3.08 \pm 0.5$ & $3.41 \pm 0.86$ & $3.58 \pm 0.76$ & $3.54 \pm 0.68$ & NS \\
\hline TG & $1 \pm 0,54$ & $1,06 \pm 0,57$ & $1,49 \pm 0,69$ & $1.41 \pm 0.69$ & NS \\
\hline TC/HDL-C & $4.15 \pm 0.91$ & $5.35 \pm 3.28$ & $6.49 \pm 4.03$ & $5.98 \pm 2.08$ & 0.012 \\
\hline LDL/HDL-C & $2.61 \pm 0.66$ & $3.7 \pm 2.62$ & $4.14 \pm 3.33$ & $4.94 \pm 1.76$ & 0.05 \\
\hline TG/HDL-C & $0.84 \pm 0.52$ & $1.2 \pm 1.41$ & $1.9 \pm 1.32$ & $1.66 \pm 0.96$ & 0.003 \\
\hline
\end{tabular}

\begin{tabular}{lllll}
\hline $\mathrm{N}$ & 11 & 18 & 16 & 35 \\
\hline
\end{tabular}

TG - triglycerides

Total cholesterol - C

Cholesterol ester - CE

HDL-C - high density lipoprotein cholesterol

LDL-C - low density lipoprotein cholesterol

Макед. фарм. билт., 66 (1) 33 - 41 (2020) 
Table 3. Age, BMI and anthropometric indexes in women grouped according to anthropometric indexes WHR and WTR

\begin{tabular}{lcccc}
\hline & group M & group N & group O & p \\
\hline age & $27.25 \pm 8.84$ & $33.06 \pm 12.91$ & $36.29 \pm 12.33$ & 0.015 \\
body height & $161.13 \pm 9.9$ & $161.53 \pm 8.53$ & $161.32 \pm 6.03$ & $\mathrm{NS}$ \\
body weight & $64.21 \pm 16.32$ & $91.69 \pm 17.3$ & $103.57 \pm 19.35$ & 0.0001 \\
BMI & $24.83 \pm 6.94$ & $35.32 \pm 6.87$ & $39.97 \pm 8.07$ & 0.0001 \\
WHR & $0.82 \pm 0.03$ & $0.95 \pm 0.06$ & $1.03 \pm 0.03$ & 0.0001 \\
WTR & $1.34 \pm 0.08$ & $1.51 \pm 0.08$ & $1.72 \pm 0.02$ & 0.0001 \\
\hline $\mathrm{N}$ & 24 & 21 & 35 & \\
\hline BMI - body mass index & WHR - waist to hip ratio WTR - waist to thigh ratio &
\end{tabular}

TG levels were significantly higher in group $\mathrm{O}$ compared to group $\mathrm{M}(\mathrm{p}<0.001)$ and also higher in group $\mathrm{N}$ compared to group $\mathrm{M}(\mathrm{p}<0.044)$. Atherogenic indexes $\mathrm{C} / \mathrm{HDL}-\mathrm{C}$, LDL/HDL-C and TG/HDL-C values in group $\mathrm{O}$ were significantly higher compared to the corresponding values in group $\mathrm{M}(\mathrm{p}<0.004 ; \mathrm{p}<0.006$; $\mathrm{p}<0.001$ ), and their values were also higher in group $\mathrm{O}$ compared to group $\mathrm{N}$, but with lower significance of the difference $(p<0.05)$ indicating lower increase of the atherogenic indexes in moderate abdominal and significant increase in extreme abdominal obese women. Their values were not different between groups $\mathrm{M}$ and $\mathrm{N}$. HDL-C levels were significantly lower in group $\mathrm{O}$ $(\mathrm{p}<0.002)$ compared to the group $\mathrm{M}$, and they were also significantly lower compared to group $\mathrm{N}(\mathrm{p}<0.006)$. The difference between group $\mathrm{M}$ and $\mathrm{N}$ was not significant.

\section{Discussion}

Obesity is a medical condition in which excess body fat has accumulated to an extent that it may have a negative effect on health (WHO, 2016). Very recently, the World Obesity Federation argued that 'obesity was considered as a chronic, relapsing, progressive, disease process' that requires intervention (Bray et al., 2017; Kyle et al., 2016; Sharma et al., 2017). Obesity is the result of complex relationships between genetic, socioeconomic, and cultural influences. Consumption patterns, urban development, and lifestyle habits influence the prevalence of obesity (Apovian, 2016). Obesity has been more precisely defined by the National Institutes of Health (the $\mathrm{NIH}$ ) as a BMI of 30 and above. Obese subjects have higher percentage of fat mass from the total body mass compared to non-obese (Snijder et al., 2002).

However, obese individuals differ not only according to the degree of excess fat, which they store, but also in the regional distribution of the fat within the body.
Obesity and central BFD are known risk factors for cardiovascular and metabolic diseases. Intra-abdominal adipose tissue, rather than total body fat, is a risk factor for metabolic conditions associated with obesity and for this reason the evaluation of intra-abdominal adipose tissue is clinically important. Because of that, effective methods for assessing visceral fat are important to investigate its role in the increased health risks in obesity. There is an increased interest in the evaluation of various methods for assessment of body composition and fat distribution and metabolic disturbances (Kim et al., 2007).

It was discovered with DXA that BMI increase in healthy women was associated with a more pronounced abdominal, visceral body fat distribution, indicating substantially higher risk for development of metabolic and cardiovascular complications, especially in postmenopausal women (Garaulet et al., 2002; Matsuzawa, 2014; Wallner et al., 2004). It was confirmed in this study with anthropometric indexes WHR and WTR, which were significantly highest $(\mathrm{p}<0.0001)$ in the $4^{\text {th }}$ group with the highest $\mathrm{BMI}>35 \mathrm{~kg} / \mathrm{m}^{2}$, confirming most expressed abdominal, visceral BFD in the $4^{\text {th }}$ group that was characterized with significantly higher $\mathrm{C} / \mathrm{HDL}-\mathrm{C}$, LDL/HDL-C and TG/HDL-C values and significantly lower HDL values compared to the $1^{\text {st }}$ and $2^{\text {nd }}$ group.

DXA measurements of fat distribution are very useful in studies related to obesity-associated disease risk. DXA indexes of central obesity legs/total, legs/trunk, android/legs as well as android/gynoid fat mass and tissue mass ratio values before the weight loss confirmed abdominal obesity in DXA examined obese women indicating higher cardiovascular risk. BMI reduction, the quantity of fat loss, body composition and BFD changes were monitored with DXA in women undergoing weight loss (Serra et al., 2017). DXA indexes of central obesity reduced to normal levels after the weight loss in several studies, which confirmed reduced abdominal BFD and consecutive normalized body composition and BFD and 
significant reduction of atherogenic lipid profile indicating reduced cardiometabolic profile risk especially in postmenopausal women. The exercise-induced change in intra-abdominal fat was related to a $16 \%$ increment in HDL cholesterol, due mostly to a $68 \%$ increment in HDL2-C (Brunzell, 1995). These findings are of concern, because elevated total $\mathrm{C}$ levels increase the risk of developing CHD. In lipid-modifying intervention studies, agents that raise HDL-C levels have been shown to reduce the incidence of major coronary events (Anthony et al., 2002).

Body composition, including fat mass, body fat distribution and muscle mass, gradually change with aging, even if the body weight and BMI remain unchanged. LBM decreases significantly, while fat mass increases and is preferentially stored in abdominal tissues (Lesser et al, 2015). Postmenopausal women have significantly more fat, more central fat distribution and less lean tissue mass than premenopausal women. The assessment of abdominal fat accumulation, especially in postmenopausal women, measurements of body composition and BFD with DXA have provided a research tool to study the metabolic effects of aging, obesity, and various wasting conditions, and are an important screening tool for the prevention of the obesity associated health complications (Kim et al., 2007; Lesser et al., 2015; Toth et al., 2000). It has been recently shown that intra-abdominal fat weight measured by CT is highly correlated with abdominal, trunk fat weight measured by DXA. Therefore, DXA measurement of regional BFD can be considered a useful tool for clinical studies, less expensive and invasive than CT or MRI. The quantification of the visceral fat becomes necessary and advantageous in clinical practice, especially through accurate and precise methods in replacement of imaging methods such as CT (Kamel et al, 1999, 2000; Roriz et al., 2014b, 2016). Some anthropometric clinical indicators are easily obtained, they are accurate in estimating visceral obesity, easy to use and have low cost (Barreira et al., 2012). Roriz et al. (2016) observed strong correlation of WTR with the visceral fat area, except in elderly women and good accuracy in discriminating the excess of this adiposity (Kahn et al., 1996, Li et al., 2010; Lu et al., 2010; Roriz, 2010, 2011, 2014a, b). In a sample representing 11437 American adults it was observed that WTR had the stronger association with mortality and that the increase in mortality risk of men was not specially related with increased waist circumference, but with a relative decrease of the thigh circumference (Kahn et al., 2012; Reis et al., 2009). Roriz et al. (2016) showed that WTR and WHR increase the prediction of mortality in individuals with normal weight and in obese ones. The WHR is an indicator used to identify the type of body fat distribution. Values above 1.00 for men and 0.85 for women indicate a distribution of the android type, central or abdominal, considered as risky for development of cardiovascular diseases due to the great concentration of fat in this region. Abdominal obesity is commonly reported as a WHR (Gradmak et al., 2010; Perissinotto et al., 2002).

Table 4. Lipid values according to their anthropometric indexes

\begin{tabular}{lcccc}
\hline \hline & group M & group N & group O & $\mathrm{p}$ \\
\hline Total lipids & $7.63 \pm 1.33$ & $7.65 \pm 2.21$ & $8.3 \pm 2.16$ & $\mathrm{NS}$ \\
Cholesterol & $4.91 \pm 0.9$ & $5.1 \pm 0.7$ & $5.35 \pm 0.97$ & $\mathrm{NS}$ \\
Cholesterol ester & $3.11 \pm 0.91$ & $3.24 \pm 0.97$ & $3.37 \pm 1.04$ & $\mathrm{NS}$ \\
HDL-C & $1.17 \pm 0.41$ & $1.14 \pm 0,43$ & $0.84 \pm 0.26$ & 0.002 \\
LDL-C & $3.3 \pm 0.79$ & $3.41 \pm 0.64$ & $3.67 \pm 0.66$ & $\mathrm{NS}$ \\
TG & $1 \pm 0.52$ & $1.43 \pm 0.73$ & $1.69 \pm 0,9$ & 0.019 \\
TC/HDL-C & $5.64 \pm 3.83$ & $5.67 \pm 2.66$ & $6.47 \pm 2.08$ & 0.005 \\
LDL/HDL-C & $3.92 \pm 3.18$ & $3.96 \pm 2.26$ & $4.49 \pm 1.49$ & 0.05 \\
TG/HDL-C & $1.25 \pm 1.41$ & $1.58 \pm 1.04$ & $2.17 \pm 1.42$ & 0.001 \\
\hline $\mathrm{N}$ & 24 & 21 & 35 & \\
\hline TG - triglycerides & HDL-C - high density lipoprotein cholesterol & \\
Total cholesterol - C & LDL-C - low density lipoprotein cholesterol &
\end{tabular}

Макед. фарм. билт., 66 (1) 33 - 41 (2020) 
The association of both age and the duration of the obesity overall with the fasting serum lipid profile are mediated via their correlations with body fat distribution that was confirmed in this study. Our results indicated higher age in the most central, abdominal, andorid obese group, also with highest BMI. Age increase was associated with pronounced abdominal obesity especially in posmenopausal women that was characterized with dyslipidemia leading to cardiocerebrovascular and other complications.

The relationship of abdominal fat to lipid levels was first demonstrated by Fujioka et al. (1987), who used CT to show a significant correlation of the abdominal visceral/subcutaneous fat ratio with $\mathrm{TG}$ and with $\mathrm{C}$. Subsequently, Despres et al. (1989) showed, in a sample of obese women, that body fat distribution, especially intra-abdominal, was a significant correlate of plasma lipoprotein levels, independent of total fatness, and also has shown that fat distribution is important in determining cardiovascular disease (CVD) risk, even in premenopausal women, who are at low risk of CVD. For a matched BMI, with a total of about $50 \%$ of body weight as fat, alterations in TG levels were found only in women whose fat was deposited centrally.

Significant association between central fat distribution and serum $\mathrm{C}$ levels, TG and LDL-C, apo B, and negative association with HDL-C was discovered by Zamboni et al. (1994). WHR, WTR and especially waist circumference and sagittal diameter correlated positively with the atherogenic lipid fractions and atherogenic indexes that was confirmed in this study (Asayama et al., 1995). Fat distribution was determined by the ratio of fat located centrally to that located in the hips and thighs. The central-fat to hip-thigh-fat ratio of distribution was related to the dyslipidemia, while total fat was not related to the dyslipidemia (Brunzell and Fujimoto, 1995). He found that intra- abdominal fat areas, determined by CT scan at the level of the umbilicus, predicted TG and HDL-C levels as well as in this study were predicted with WTR. WTR was a better predictor of atherogenic lipid fractions than WHR. HDL-C had a strong inverse correlation with TG levels.

A great number of studies, as well as this study, demonstrated a relationship between central body fat distribution and elevated plasma TG and decreased HDLC subfraction 2, also a reduced HDL 2-C to HDL3Cholesterol ratio, hypoalphalipoproteinemia, elevated apoliprotein B concentration, a greater proportion of small, dense LDL particles and an increased LDL-C to HDL-C ratio, also associated with hyperinsulinemia resulting from an insulin resistant state (Ascaso et al., 2007). Reduction of LDL-C levels is the primary (main) target of therapy.

In an attempt to optimize the predictive capacity of the lipid profile, several lipoprotein ratios or "atherogenic indices" C/HDL-C, LDL/HDL-C and TG/HDL-C have been defined. These ratios can provide information on risk factors difficult to quantify by routine analyses and could be a better mirror of the metabolic and clinical interactions between lipid fractions. Low HDL-C levels are frequently associated with raised levels of plasma TG and increased risk of cardiovascular disease and increase of TG/HDL-C ratio. TG/HDL-C ratio may be a better predictor of insulin resistance and cardiovascular disease. Obesity and central body fat distribution as well as dyslipidemic profile, and increased C/HDL-C known as the atherogenic or Castelli index, LDL/HDL-C and TG/HDL-C ratios values are especially important components and indicators of cardiovascular risk. Their predictive value is greater than the isolated parameters. LDL/HDL-C ratio is a risk indicator with greater predictive value than LDL-C. C/HDL-C ratio is considered a more sensitive and specific index of cardiovascular risk than total C (Ingelsson et al., 2007; Nam et al., 2006; Mounier-Vehier et al., 2007; Natarajan et al., 2003; Walton et al., 1995).

\section{Conclusion}

Clinical anthropometric indicators WHR and WTR were used in this study in estimating visceral, abdominal obesity and their relationship with dyslipidemic profile and atherogenic indexes in healthy women that indicated the need to intervene earlier and more effectively in the prevention and treatment of cardiovascular and metabolic risks in abdominal, visceral obese women with dyslipidemic, atherogenic profile.

\section{References}

Anthony, S.W., Dimitri, P. M., 2002. Beyond LDL-C - The Importance of Raising HDL-C. Curr. Med. Res. Opin. 18(1), 36-44. Available at: https://doi.org/10.1185/030079902125000165.

Apovian, C.M., 2016. Obesity: Definition, Comorbidities, Causes, and Burden. Am. J. Manag. Care 22(7 Suppl), S176-S185.

Asayama, K., Kayashibe, H., Dobashi, K., 1995. Relationships between biochemical abnormalities and anthropometric indices in overweight, adiposity and body fat distribution in Japanese school children. Int. J. Obes. Relat. Metab. Disord. 19, 253-259.

Ascaso, J., González, S.P., Hernández, M.A., Mangas, R.A., Masana, L., Millan, J., Pallardo, L.F., Pedro-Botet, J., Perez, J.F., Pinto, X., Plaza, I., Rubies, J., Zuniga, M., 2007. Management of dyslipidemia in the metabolic syndrome: recommendations of the Spanish HDLForum. Am. J. Cardiovasc. Drugs 7(1), 39-58.

Barreira, T.V., Staiano, A.E., Harrington, D.M., Heymsfield, S.B., Smith, S.R., Bouchard, Katzmarzyk, P.T., 2012. Anthropometric correlates of total body fat, abdominal adiposity, and cardiovascular disease risk factors in a biracial sample of men and women. Mayo Clin. Proc. 87(5), 452-460. Available at: https://doi.org/10.1016/j.mayocp.2011.12.017 
Bray, G.A., Kim, K.K., Wilding, J.P.H., World Obesity Federation, 2017. Obesity: a chronic relapsing progressive disease process. A position statement of the World Obesity Federation. Obes. Rev. 18(7), 715-723. Available at: https://doi.org/10.1111/obr.12551.

Brunzell, J.D., Fujimoto, W.Y., 1995. Body fat distribution and dyslipidemia. Am. J. Med. 99(5), 457-458.

Després, J.P., Moorjani, S., Ferland, M., Tremblay, A., Lupien, P.J., Nadeau, A., Pinault, S., Thériault, G., Bouchard, C., 1989. Adipose tissue distribution and plasma lipoprotein levels in obese women. Importance of intra-abdominal fat. Arteriosclerosis. 9(2), 203-210. Available at: https://doi.org/10.1161/01.ATV.9.2.203.

Fujioka, S., Matsuzawa, Y., Tokunaga, K., Tarui, S., 1987. Contribution of intra-abdominal fat accumulation to the impairment of glucose and lipid metabolism in human obesity. Metabolism 36(1), 54-59. Available at: https://doi.org/10.1016/0026-0495(87)90063-1.

Garaulet, M., Pérez-Llamas, F., Baraza, J.C., Garcia-Prieto, Fardy, P.S., Tébar, F.J., Zamora, S., 2002. Body fat distribution in pre-and post-menopausal women: metabolic and anthropometric variables. J. Nutr. Health. Aging 6(2), 123-126.

Gradmark, A.M.I., Rydh, A., Renstrom, F., De Lucia-Rolfe, E., Sleigh, A., Nordstrom, P., Brage, S., Franks, P.V., 2010. Computed tomography-based validation of abdominal adiposity measurements from ultrasonography, dual-energy X-ray absorptiometry and anthropometry. Br. J. Nutr. 104(4), 582-588. Available at: https://doi.org/10.1017/S0007114510000796

Ingelsson, E., Schaefer, E.J., Contois, J.H., McNamara, L., Sullivan, J., Keyes, M.J., Pencina, M.J., Schoonmaker, C., Wilson, P.W., D'Agostino, R.B., Vasan, R.S., 2007. Clinical utility of different lipid measures for prediction of coronary heart disease in men and women. JAMA 298(7), 776-785. Available at: https://doi.org/10.1001/jama.298.7.776.

Kahn, H.S., Austin, H., Williamson, D.F., Arensberg, D., 1996. Simple anthropometric indices associated with ischemic heart disease. J. Clin. Epidemiol. 49(9), 1017-1024. Available at: https://doi.org/10.1016/0895-4356(96)001138 .

Kahn, H.S., Bullard, K.M., Barker, L.E., Imperatore, G., 2012. Differences between adiposity indicators for predicting allcause mortality in a representative sample of United States non-elderly adults. PLOS One 7(11), e50428. Available at: https://doi.org/10.1371/journal.pone.0050428.

Kamel, E.G., McNeill, G., Han, T.S., Smith, F.W., Avenell, A., Davidson, L., Tothil, P., 1999. Measurement of abdominal fat by magnetic resonance imaging, dual-energy X-ray absorptiometry and anthropometry in non-obese men and women. Int. J. Obes. Relat. Metab. Disord. 23(7), 686-692. Available at: https://doi.org/10.1038/sj.ijo.0800904.

Kamel, E.G., McNeil, G., Van Wajk, M.C., 2000. Usefulness of anthropometry and DXA in predicting intra-abdominal fat in obese men and women. Obes. Res. 8(1), 36-42. Available at: https://doi.org/10.1038/oby.2000.6.

Kim, J.S., Yoo, S.M., Kim, K.N., Lee, S.Y., 2007. Comparison of DXA and CT for truncal obesity in adult women related to metabolic complications. J. Korean Acad. Fam. Med. 28(9), 675-681. Available at: https://doi.org/10.1038/oby.2010.5.
Kyle, T.K., Dhurandhar, E.J., Allison, D.B., 2016. Regarding obesity as a disease. Evolving policies and their implications. Endocrinol. Metab. Clin. North Am. 45(3), 511-520. Available at: https://doi.org/10.1016/j.ecl.2016.04.004.

Lesser, I.A., Dick, T.J., Guenette, J.A., Hoogbruin, A., Mackey, D.C., Singer, J., Lear, S.A., 2015. The association between cardiorespiratory fitness and abdominal adiposity in postmenopausal, physically inactive South Asian women. Prev. Med. Rep. 2, 783-787. Available at: https://doi.org/10.1016/j.pmedr.2015.09.007.

Li, C., Ford, E.S., Zhao, G., Kahn, H.S., Mokdad, A.H., 2010. Waist-to thigh ratio and diabetes among US adults: the Third National Health and Nutrition Examination Survey. Diabetes Res. Clin. Pract. 89(1), 79-87. Available at: https://doi.org/10.1016/j.diabres.2010.02.014.

Lu, B., Zhou, J., Waring, M.E., Parker, D.R., Eaton, C.B., 2010. Abdominal obesity and peripheral vascular disease in men and women: a comparison of waist-to-thigh ratio and waist circumference as measures of abdominal obesity. Atherosclerosis 208(1), 253-257. Available at: https://doi.org/10.1016/j.atherosclerosis.2009.06.027.

Matsuzawa, Y., 2014. Obesity and metabolic syndrome: the contribution of visceral fat and adiponectin. Diab. Manag. 4(4), 391-401. Available at: https://doi.org/10.2217/dmt.14.30.

Mounier-Vehier, C., Stephan, D., Aboyans, V., 2007. Vascular group (SFC-Societe francaise de medecine vascular). The best of vascular medicine in 2006. Arch. Mal. Coeur. Vaiss. 100, 47-55.

Nam, B.H., Kannel, W.B., D’Agostino, R.B., 2006. Search for an optimal atherogenic lipid risk profile: from the Framingham Study. Am. J. Cardiol. 97(3), 372-375. Available at: https://doi.org/10.1016/j.amjcard.2005.08.055.

Natarajan, S., Glick, H., Criqui, M., Horowitz, D., Lipsitz, S.R., Kinosian, B., 2003. Cholesterol measures to identify and treat individuals at risk for coronary heart disease. Am. J. Prev. Med. 25(1), 50-57. Available at: https://doi.org/10.1016/s0749-3797(03)00092-8.

Perissinotto, E., Pisent, C., Sergi, G., Grigoletto, F., 2002. Anthropometric measurements in the elderly: age and gender differences. Br. J. Nutr. 87(2), 177-186. Available at: https://doi.org/10.1079/BJN2001487.

Reis, J.P., Araneta, M.R., Wingard, D.L., Macera, C.A., Lindsay, S.P., Marshall, S.J., 2009. Overall obesity and abdominal adiposity as predictors of mortality in U.S. white and black adults. Ann. Epidemiol. 19(2), 134-142. Available at: https://doi.org/10.1016/j.annepidem.2008.10.008.

Roriz, A.K.C., de Oliveira, C.C., Moreira, P.A., Eickemberg, M., Medeiros, J.M.B., Sampaio, L.R. 2011. Methods of predicting visceral fat in Brasilian adults and older adults: a comparison between anthropometry and computerized tomography. Arch. Latinoamericanos Nutricion 61(1), 512.

Roriz, A.K.C., Passos, L.C.S., de Oliveira, C.C, Eickemberg, M., Moreira P. De. A., Sampaio, L.R., 2014a. Evaluation of the Accuracy of Anthropometric Clinical Indicators of Visceral Fat in Adults and Elderly. PLOS ONE 9(7), e103499. Available at: https://doi.org/10.1371/journal.pone.0103499. 
Roriz, A.K.C., Passos, L.C.S., de Oliveira, C.C., Eickemberg, M., Moreira, P.deA., Sampaio, L.R., 2014 b. Discriminatory power of indicators predictors of visceral adiposity evaluated by computed tomography in adults and elderly individuals. Nutr. Hosp. 29(6), 1401-1407. Available at: https://doi.org/10.3305/nh.2014.29.6.7185.

Roriz, C., Karla, A., Passos, S., Carlos, L., Carolina, C.deO., Michaela, E., Pricilla, De.A.M., Lilian, B.R., 2016. Anthropometric clinical indicators in the assessment of visceral obesity: an update. Nutr. Clín. Diet. Hosp. 36(2), 168-179. Available at: https://doi.org/10.12873/362carneirororiz

Serra, M.C., Blumental, J.B., Addison, O.R., Miller, A.J., Goldberg, A.P., Ryan, A.S., 2017. Effects of weight loss with and without exercise on regional body fat distribution in postmenopausal women. Ann. Nutr. Metab. 70, 312320. Available at: https://doi.org/10.1159/000475766.

Sharma, A.M, Campbell-Scherer, D.L., 2017. Redefining obesity: beyond the numbers. Obesity 25(4), 660-661. Available at: https://doi.org/10.1002/oby.21801.

Snijder, M.B., Visser, M., Dekker, J.M., Seidell, J.C., Fuerst, T., Tylavsky, F., Cauley, J., Lang, T., Nevitt, M., Harris, T.B., 2002. The prediction of visceral fat by dual-energy X-ray absorptiometry in the elderly: a comparison with computed tomography and anthropometry. Int. J. Obes. Relat. Metab. Disord. 26(7), 984-993. Available at: https://doi.org/10.1038/sj.ijo.0801968.

Toth, M.J., Tchernof, A., Sites, C.K., 2000. Menopause-related changes in body fat distribution. Ann. N.Y. Acad. Sci. 904, 502-506. Available at: https://doi.org/10.1111/j.17496632.2000.tb06506.x.

Vallgarda, S., Nielsen, M.E.J., Hansen, A.K.K., Cathaoir, K.O., Hartlev, M., Holm, L., Christensen, B.J., Jensen, J.D., Sorensen, T.I.A., Sandoe, P., 2017. Should Europe follow the US and declare obesity a disease?: a discussion of the so-called utilitarian argument. Eur. J. Clin. Nutr. 71(11), 1263-1267. Available at: https://doi.org/10.1038/ejen.2017.103.

Wallner, S.J., Luschnigg, N., Schnedl, W.J., Lahousen, T., Sudi, K., Crailsheim, K., Moller, R., Tafeit, E., Horejsi, R., 2004. Body fat distribution of overweight females with a history of weight cycling. Int. J. Obes. Relat. Metab. Disord. 28(9), 1143-1148. Available at: https://doi.org/10.1038/sj.ijo.0802736.

Walton, Ch., Lees, B., Crook, D., Worthington, M., Godsland, I.F., Stevenson, J.C., 1995. Body fat distribution, rather than overall adiposity, influences serum lipids and lipoproteins in healthy men independently of age. Am. J. Med. 99(5), 459-64. Available at: https://doi.org/10.1016/S0002-9343(99)80220-4.

WHO. 2016. "Obesity and overweight Fact sheet N³11".

Zamboni, M., Armellini, F., Cominacini, L., Turcato, E., Todesco, T., Bissoli, L., Micciolo, R., Bosello, O., 1994. Obesity and regional body-fat distribution in men: separate and joint relationships to glucose tolerance and plasma lipoproteins. Am. J. Clin. Nutrit. 60, 682-687.

\title{
Резиме
}

\section{Дислипидемичен профил кај здрави жени во однос на дистибуцијата на масти}

\author{
Славица Шубеска Стратрова ${ }^{1}$, Елена Костова ${ }^{2}$ \\ ${ }^{1}$ Клиника за ендокринологија, дијабетес и метаболички нарушувања, \\ Медицински факултет, Универзитет „Св. Кирил и Методиј”, Мајка Тереза 17, \\ 1000 Скопје, Република Северна Македонија \\ ${ }^{2}$ Институт за претклиничка и клиничка фармакологија со токсикологија, \\ Медииински факултет, Универзитет „Св. Кирил и Методиј”, 50 Дивизија 6, \\ 1000 Скопје, Република Северна Македонија
}

Клучни зборови: абдоминална дебелина, антропометриски индекси, липиден профил, атерогени индекси

Абдоминалната дебелина е поврзана со особено неповолен липиден профил. Целта на оваа студија беше да се утврдат карактеристиките на дислипидемичниот профил кај жени со екстремна абдоминална дебелина утврдена антропометриски. Липидниот профил и атерогените индекси беа одредени кај 80 здрави жени, групирани во 4 групи според нивниот индекс на телесна маса (BMI) и групирани во 3 групи според нивната телесна дистрибуција на масти (BFD) со помош на антропометриските индекси, количници на обемите на половина/колк (WHR) и половина/бут (WTR): група M со нормален BFD (WHR $<0,85$ и WTR $<1,45$ ), група N со умерена (WHR 0,85-1 и WTR 1,45-1,7) и групата O со екстремно изразена абдоминална BFD. 
Нивоата на HDL-холестеролот (HDL-C) $(0,84 \pm 0,26 \mathrm{mmol} / \mathrm{L})$ беа значајно најниски во групата $\mathrm{O}(\mathrm{p}<0,002)$, и значајно пониски во однос на групата $\mathrm{N}(1,14 \pm 0,43 \mathrm{mmol} / \mathrm{L})(\mathrm{p}<0,006)$. Нивоата на триглицеридите (TG) беа значајно повисоки во групата О споредено со групата $\mathrm{M}(\mathrm{p}<0.001)$, а исто така повисоки во групата $\mathrm{N}$ во споредба со групата M ( $<<0,044)$. Вредностите на атерогените индекси C/HDL-C, LDL/HDL-C и TG/HDL-C во групата O беа значајно повисоки во споредба со соодветните вердности во групата $\mathrm{M}(\mathrm{p}<0,004 ; \mathrm{p}<0,006 ; \mathrm{p}<0,001)$, но нивните вредности исто така беа повисоки во групата $\mathrm{O}$ во однос на групата $\mathrm{N}$, но со помала значајност на разликата $(\mathrm{p}<0,05)$ што укажува на помало зголемување на атерогените индекси кај умерено и значително зголемување кај екстремно абдоминалните дебели жени.

Дислипидемичниот профил и високите атерогени индекси кај жени со абдоминална дебелина со сигнификантно највисоки вредности на WHR, WTR и BMI укажуваат на потребата да се интервенира порано и поефикасно во превенцијата и третманот на кардиоваскуларните и метаболичките ризици. 
